\title{
Pemodelan 2D Batuan Bawah Permukaan Daerah Mamuju Sulawesi Barat dengan Menggunakan Metode Magnetik
}

\author{
Muhammad Irsyad $^{1, \uparrow}$, Sutrisno $^{1}$, Dwi Haryanto ${ }^{2}$ \\ ${ }^{1}$ Program Studi Fisika, Fakultas Sains dan Teknologi Universitas Islam Negeri Syarif Hidayatullah \\ Jakarta \\ ${ }^{2}$ Pusat Teknologi Bahan Galian Nuklir BATAN (PTBGN-BATAN) \\ †corresponding author: muhammad.irsyad13@mhs.uinjkt.ac.id
}

\begin{abstract}
Abstrak. Batuan merupakan benda yang berasal dari magma yang mendingin di dalam bumi. Untuk mengetahui kondisi batuan perlu di lakukan penelitian. Mamuju merupakan daerah yang sedang hangat dalam perbincangan peneliti tentang bagaimana kandungan di bawah permukaan daerah Mamuju, Sulawesi Barat. Daerah ini juga merupakan daerah yang diteliti oleh instansi-instansi pemerintah termasuk PTBGN-BATAN. Penelitian ini bertujuan untuk melakukan pemodelan bawah permukaan bumi. Tujuannya untuk memberikan informasi tentang kondisi baik itu bentuk maupun kedalaman batuan. penelitian ini menggunakan metode magnetik dan metode ini merupakan metode yang tepat untuk membuat model bawah permukaan bumi. Hasil interpretasi kualitatif diperoleh peta kontur intensitas magnetik total dan anomali magnetik. Peta kontur intensitas magnetik total memiliki nilai sebesar 41286,5 - 42280 nT. Sedangkan anomali magnetik memiliki nilai -760,1 - 231,8 nT. Daerah A dan daerah B merupakan daerah yang memiliki anomali tinggi. Hasil interpretasi kuantitatif didapat ada 4 model bawah permukaan yang masing-masing terdapat batuan yang sama yaitu batuan breksi dengan nilai suseptibilitas 0,0006 - 0,00075 satuan cgs dan batuan lava dengan nilai suseptibilitas $0.001-0.0015$ satuan cgs. daerah yang dilakukan pemodelan fokus pada daerah Hulu Mamuju, hal ini disebabkan karena menurut peta kontur daerah tersebut merupakan daerah yang memiliki anomali magnetik yang tinggi.
\end{abstract}

Kata kunci: Anomali Magnetik, Intensitas Magnetik Total, Suseptibilitas.

Abstract. The rocks are objects derived from the magma cooled in the earth. To determine the condition of the rock is necessary to do research. Mamuju is an area that is warm in conversation investigators about how the content of subsurface area Mamuju, West Sulawesi. This area is also the area investigated by government agencies including PTBGN-BATAN. This study aimed to modeling subsurface. The goal is to provide information about the condition of both the shape and depth of rock. This study uses a magnetic method and this method is an appropriate method to create a model of the earth's subsurface. Qualitative interpretation of results obtained contour map of total magnetic intensity and magnetic anomalies. The total magnetic intensity contour map has a value of 41286.5 to $42280 \mathrm{nT}$. While the magnetic anomaly has a value of -760.1 - 231.8 nT. Area A and area B is an area that has a high anomaly. Results obtained quantitative interpretation there are 4 models of the subsurface that each contained the same rock is rock breccia with values susceptibility of 0.0006 to 0.00075 cgs units and lava rock with susceptibility value $0.001-0.0015 \mathrm{cgs}$ unit. modeling area focuses on upstream area Mamuju, this is because according to the contour map of the area is an area that has a high magnetic anomaly.

Keyword: Magnetic Anomaly, Susceptibility, Total magnetic intensity

\section{PENDAHULUAN}

Sumber daya alam di Indonesia diberkahi berbagai macam bahan untuk kebutuhan hidup manusia. Berbagai kalangan mulai melakukan penambangan di daerah yang memiliki potensi. Berbagai sumber daya alam seperti mineral, batubara, batuan, logam bahkan sumber daya alam yang langka seperti uranium, thorium dan lain sebagainya.

Mamuju merupakan ibu kota Provinsi Sulawesi Barat hasil pemekaran dari Provinsi Sulawesi Selatan pada tahun 2004. Beberapa kecamatan di kabupaten Mamuju merupakan daerah yang memiliki laju dosis radiasi (radioaktivitas) tinggi [1]. 
Geofisika merupakan salah satu cabang ilmu pengetahuan yang menerapkan prinsipprinsip fisika untuk mengetahui dan memecahkan masalah yang berhubungan dengan bumi, atau dapat pula diartikan mempelajari bumi dengan menggunakan prinsip-prinsip fisika [2]. Beberapa metode dalam ilmu geofisika diantaranya: magnetik, seismik, gaya berat, geolistrik, elektromagnetik.

Batuan di bawah permukaan bumi tidak dapat dilihat dengan kasat mata. Para peneliti di dunia melakukan penelitian yang bertujuan untuk mengetahui kondisi bawah permukaan bumi baik itu bemtuk dan kedalaman. Oleh karena itu peneliti mencoba untuk melakukan riset tentang bagaimana mengetahui kondisi bawah permukaan bumi. Untuk mengetahuinya dibuat model bawah permukaan daerah survei yang nantinya bisa dijadikan informasi baik itu informasi komersil maupun non komersil. Salah satu metode yang tepat untuk membuat model bawah permukaan bumi adalah metode magnetik.

Penelitian ini bertujuan untuk membuat pemodelan dan analisis peta kontur anomali magnetik untuk menentukan daerah yang memiliki anomali magnetik tinggi. melakukan interpretasi model anomali magnetik dan menentukan nilai suseptibilitas. sebagai penelitian awal sebelum dilakukan penelitian lebih lanjut.

\section{Geologi Daerah Penelitian}

Pulau Sulawesi secara geologi memiliki tatanan yang kompleks. Tektonik yang sangat kompleks ini disebabkan oleh interaksi dari tiga lempeng yang bergerak aktif, yaitu Lempeng Benua Australia yang bergerak ke utara, pergerakan Lempeng Samudera Pasifik yang bergerak ke barat, dan Lempeng Benua Eurasia yang relatif bergerak ke selatan tenggara [1].

Berdasarkan struktur litotektonik, Sulawesi dan pulau-pulau sekitarnya dibagi menjadi empat, yaitu; Mandala Barat (West \& North Sulawesi Volcano-Plutonik Arc) merupakan bagian ujung timur Paparan sunda sebagai jalur magmatik yang, Mandala Tengah (Central Sulawesi Metamorphic Belt) merupakan bagian dari blok Australia yaitu berupa batuan malihan yang ditumpangi batuan bancuh, mandala Timur (Eats Sulawesi Ophiolite Belt) merupakan segmen dari kerak samudera berimbrikasi dan sedimen berumur Trias-Miosen yaitu berupa ofiolit, keempat adalah fragmen benua Banggai-Sula-Tukang Besi, kepulauan paling timur dan tenggara Sulawesi merupakan pecahan benua yang berpindah ke arah barat karena strike-slip faults dari New Guinea [3].

Daerah penelitian terletak di Sulawesi Barat yang termasuk ke dalam kelompok Mandala Barat. Dimana kelompok ini dengan lintasan memanjang dari lengan utara sampai dengan lengan selatan pulau Sulawesi. Secara umum daerah ini merupakan batuan sedimen berusia mesozoikum-tersier dan batuan malihan yang terdiri dari batuan vulkanik-plutonik berusia Paleogen-Kuarter dengan [3].

Stratigrafi Sulawesi bagian barat (Gambar 1) didominasi oleh batuan Neogen tetapi di dalamnya termasuk juga formasi batuan berumur jura. Formasi Mamuju terdiri atas napal, batupasir gampingan nafal tuffan, dan batugamping pasiran bersisipan tufa. Formasi ini mempunyai anggota Tapalang (Tmmt) yang terdiri dari batu gamping koral, batu gamping bioklastik, dan napal yang banyak mengandung moluska [3]. Daerah penelitian terdapat beberapa satuan batuan yaitu; Breksi Adang (BrkA), Breksi Ampalas (Btpsk), Lava Adang (Lva), Lava Dome (Lvd), Konglomerat Vulkanik (Klg), Batugamping Terumbu (Bgpt) dan Batu gamping (Btgp). 


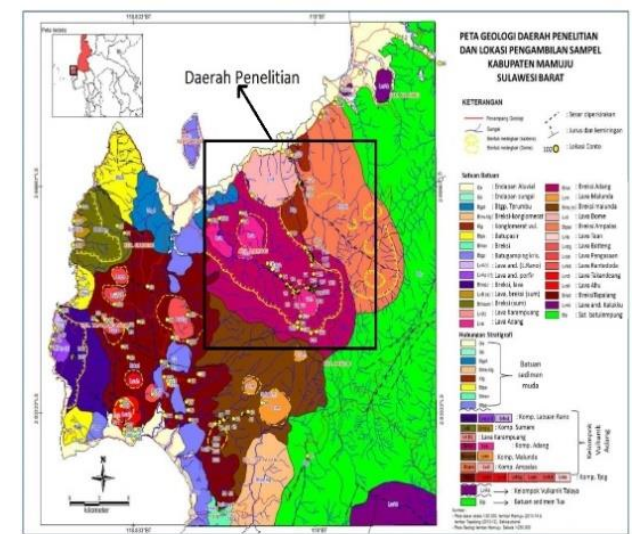

GAMBAR 1. Peta Geologi Sulawesi Barat [1].

\section{METODE PENELITIAN}

Gaya magnetik diakibatkan oleh adanya dua buah kutub yang terpisah dengan jarak $\mathrm{r}$ dimana dua kutub tersebut masing-masing memiliki muatan $P_{1}$ dan $P_{2}$. Jika kedua kutub memiliki tanda yang tidak sama akan tarik menarik, sedangkan jika sama akan tolak menolak. sesuai dengan persamaan berikut [4].

$$
\vec{F}=\frac{1}{\mu_{0}} \frac{m_{1} m_{2}}{r^{2}} \hat{r}
$$

dimana:

$\vec{F} \quad=$ Gaya Coulomb (N)

$m_{1} m_{2} \quad=$ kutub magnetik yang memiliki muatan $(\mathrm{C})$

$\mu_{0} \quad=$ konstanta permeabilitas magnetik (dalam ruang hampa $\left.=1\right)$

$r \quad=$ jarak antara dua kutub $(\mathrm{m})$

$\hat{r} \quad=$ vektor satuan

Kuat medan magnet adalah besar medan magnet yang timbul pada suatu titik dalam ruang diakibatkan jarak di antara dua kutub tersebut. Kuat medan magnet $(\vec{H})$ didefinisikan sebagai gaya persatuan kutub magnet (m), seperti persamaan (2):

$$
\vec{H}=\frac{m}{\mu r^{2}} \hat{r}
$$

dimana:

$\vec{H} \quad=$ kuat medan magnet $(\mathrm{A} / \mathrm{m})$

$\mathrm{m} \quad=$ kuat kutub magnet $(\mathrm{emu})$

$\mathrm{r} \quad=$ jarak $(\mathrm{m})$

$\hat{r} \quad=$ vektor satuan

Suseptibilitas merupakan parameter fisika yang sangat penting dalam eksplorasi geomagnet. Suseptibilitas adalah kemampuan suatu benda atau batuan untuk termagnetisasi yang diakibatkan oleh pengaruh medan magnet. Hubungan suseptibilitas dalam emu dan dalam SI dinyatakan sebagai [5]:

$$
k_{S I}=4 \pi k_{e m u}^{\prime}
$$

Dimana $k_{S I}$ adalah suseptibilitas magnetik dalam SI dan $k_{e m u}^{\prime}$ adalah suseptibilitas dalam emu.

Medan magnet bumi secara sederhana dapat digambarkan sebagai medan magnet yang berbentuk batang magnet raksasa yang terletak di dalam inti bumi. Medan magnet bumi terkarakterisasi oleh parameter fisis atau disebut juga elemen medan magnet bumi. Sudut 
deklinasi $(D)$ merupakan sudut yang dibentuk antara kutub magnetik Bumi dengan kutub utara geografis Bumi sedangkan sudut inklinasi (I) adalah sudut vertikal yang dibentuk antara medan magnetik total dengan medan magnetik horizontal Bumi [4].

Pengambilan data magnetik yang dilakukan merupakan langkah awal untuk mengetahui lapisan batuan di bawah permukaan. Data yang diperoleh masih mengandung berbagai macam pengaruh medaan magnet seperti medan magnet bumi maupun gangguan medan magnet dari luar. Oleh sebab itu diperlukan adanya perbaikan atau koreksi-koreksi. Koreksi-koreksi ini nantinyakan menghasilkan anomali magnetik yang akan menunjukkan adanya anomali di daerah survei. Koreksi koreksi tersebut adalah [6]:

1. Koreksi Harian

Koreksi harian (diurnal correction) merupakan nilai medan magnetik bumi yang terjadi penyimpangan akibat adanya perbedaan waktu dan efek radiasi matahari dalam satu hari.

2. Koreksi IGRF (International Geomagnetic Reference Field)

Data hasil pengukuran medan magnetic yang didapatkan pada dasarnya adalah konstribusi dari tiga komponen dasar, yaitu medan magnetik utama bumi, medan magnetik luar dan medan anomali. Nilai medan magnetik utama merupakan nilai IGRF. Jika nilai medan magnetik utama dihilangkan dengan koreksi harian, maka kontribusi medan magnetik utama dihilangkan dengan koreksi IGRF. Koreksi IGRF dapat dilakukan dengan cara mengurangkan nilai IGRF terhadap nilai medan magnetik total yang telah terkoreksi harian pada setiap titik pengukuran pada posisi geografis yang sesuai.

\section{Anomali Magnetik}

Anomali magnetik adalah medan magnetik yang berasal dari berbagai macam batuan yang ada di bawah permukaan bumi. Anomali ini yang nantinya akan diolah dan diteliti untuk menentukan batuan apa saja yang ada di bawah permukaan daerah survei. Anomali magnetik didapat dari persamaan [7]:

$$
H_{A}=H_{t o t}-H_{I G R F}-H_{V H}
$$

\section{Pengangkatan Ke Atas (Upward Continuation)}

Suatu proses pengubahan data medan potensial yang diukur pada suatu bidang permukaan, menjadi data yang seolah-olah diukur pada bidang permukaan lebih ke atas disebut kontinuasi ke atas. Metode ini juga merupakan salah satu metode yang sering digunakan karena dapat mengurangi efek dari sumber anomali dangkal [8].

\section{Reduksi ke Kutub (Reduction to The Pole)}

Operasi ini memperlihatkan anomali dipole (positif dan negatif) yang akan ditransformasikan menjadi anomali monopole (positif) (Gambar 3.6). Mengubah nilai inklinasi sebenarnya menjadi ke arah vertikal. Transformasi ini menyederhanakan peta medan total dan secara relatif pengoperasiannya mudah dilakukan di lintang magnetik tinggi [9]. Akan tetapi proses ini akan mengalami kesulitan jika dilakukan di daerah khatulistiwa [4]. Secara umum jika magnetisasi dan medan lingkungan yang tidak vertikal, distribusi simetris magnetisasi akan menghasilkan kemiringan kurva anomali magnetik simetrisnya.

\section{HASIL DAN PEMBAHASAN}

Anomali ini merupakan anomali magnet yang berada di bawah permukaan bumi. Anomali ini menunjukkan anomali terbesar berada pada daerah A dan daerah B. Daerah A memiliki anomali yang luas, terdapat ada 2 puncak dengan anomali tinggi. Anomali ini berada pada nilai 23,4 - 231,8 nT. Anomali pada daerah B memiliki luas yang lonjong kea rah bawah. 
Anomali ini juga memiliki 2 puncak yang menandakan adanya anomali tinggi. Anomali pada daerah B beraada pada nilai sekitar 8,7-231,8 nT. Anomali ini jika dibandingkan dengan peta intensitas magnetik akan terlihat mirip karena faktor variasi harian dan IGRF relatif kecil. Hal ini terjadi karena faktor-faktor tersebut sangat kecil memberikan dampak terhadap perubahan anomali, lain halnya apabila terjadi faktor-faktor seperti badai matahari dan badai magnetik. Nilai anomali magnetik yang ditampilkan yaitu $-760,1-231,8 \mathrm{nT}$. Peta anomali magnetik dapat dilihat pada Gambar 2.

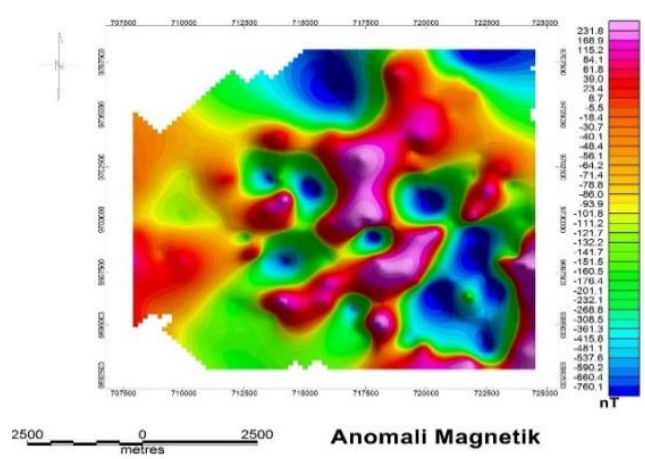

GAMBAR 2. Nilai Anomali Magnetik Daerah Penelitian

Pengolahan lebih lanjut yaitu melakukan filter upward continuation (pengangkatan ke atas). Filter ini bertujuan untuk membuat anomali menjadi regional maupun residual. Filter ini biasanya dilakukan untuk menghilangkan anomali pengganggu/noise yang berada di sekitar daerah penelitian. Noise ini bisa disebabkan oleh bangunan di sekitar tempat pengambilan data, tiang listrik, pipa saluran air, dan sebagainya. Peristiwa ini terjadi karena upward continuation menghilangkan sebagian besar anomali yang terdapat pada permukaan bumi. Nilai pada daerah A dan daerah $\mathrm{B}$ setelah dilakukan upward mengalami pengurangan, dimana nilainya yaitu daerah A sebesar -68,9 - -12,6 nT sedangkan pada daerah B sebesar -64 - 13,1 nT. Nilai anomali yang tampak Filter yang digunakan untuk tahapan berikutnya adalah upward continuation $1000 \mathrm{~m}$. Nilai yang dihasilkan pada filter ini yaitu $-485,3-13,1 \mathrm{nT}$. Peta upward continuation $1000 \mathrm{~m}$ bisa dilihat pada Gambar 3 .

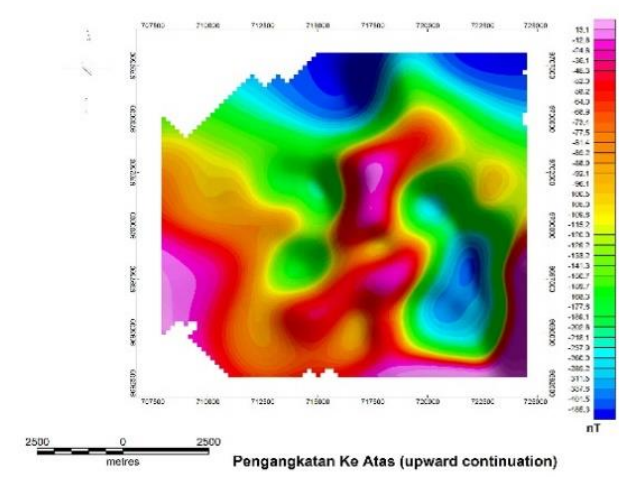

GAMBAR 3. Peta Pengangkatan Ke Atas (Upward Continuation) 1000 m.

Proses reduce to pole dilakukan untuk mengubah anomali dipole menjadi monopole. Proses ini bertujuan untuk memudahkan peneliti dalam membuat model bawah permukaan, dimana anomali yang tampak akan menunjukkan model batuan yang ada di bawahnya. Filter yang digunakan pada Proses reduce to pole adalah filter upward continuation 1000. Hal ini dilakukan karena filter ini yang mendukung dengan peta geologi daerah penelitian dan anomali yang tampak peta sudah menghilangkan faktor-faktor anomali pengganggu. Nilai yang dihasilkan pada proses ini yaitu $56-(-440)$ nT. 


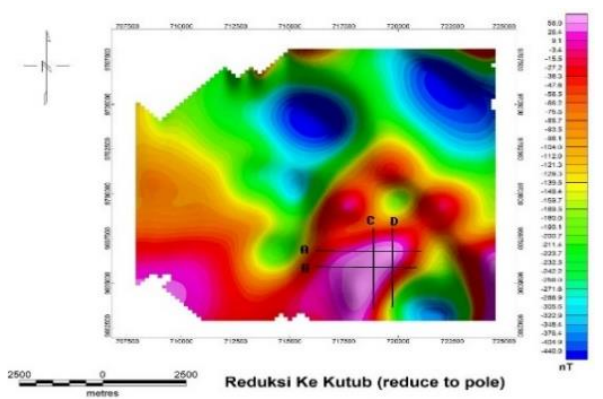

GAMBAR 4. Peta Reduksi ke Kutub (Reduced to Magnetic Pole)

Interpretasi kuantitatif dilakukan dengan pembuatan model bawah permukaan. Proses interpretasi yang bertujuan untuk memberikan informasi berupa gambaran bawah permukaan bumi maupun batuan yang ada di dalamnya. Pada penelitian ini dibuat 4 model yang berfokus pada daerah yang memiliki anomali magnetik yang besar dimana posisi anomali tersebut berada pada hulu Mamuju. Hulu Mamuju merupakan daerah dataran tinggi di Mamuju. Daerah ini merupakan prospek yang bagus untuk diteliti, dimana daerah ini memiliki nilai anomali yang relatif tinggi.

Profil-profil yang diambil merupakan daerah yang memiliki nilai anomali magnetik yang besar. Nilai anomali magnetik ini juga cocok dengan peta geologi di Hulu Mamuju. Daerah ini merupakan daerah yang bagus untuk di teliti karena peta reduce to pole menunjukkan adanya anomali di daerah ini. Peta geologi tersebut didapat dari penelitian sebelumnya yang meneliti geologi di daerah Mamuju.

Keempat profil yang ada akan dibuat 4 model bawah permukaan bumi dan ditentukan dengan nilai suseptibilitas dan bentuk batuan. Model pertama pada profil 1 terdapat 2 batuan yang akan dibuatkan model bentuk maupun kedalaman. Model tersebut terdapat batuan breksi dan lava, dimana breksi memiliki nilai suseptibilitas sebesar 0,0004 dan lava memiliki nilai suseptibilitas 0,001 dengan satuan cgs. Adapun panjang profil 1 adalah sepanjang 5,5 km dengan kedalaman sekitar $1 \mathrm{~km}$. Batuan lava mengalami intrusi dari bawah permukaan bumi dan keluar menembus batuan breksi. Peristiwa ini diyakini telah terjadi jutaan tahun yang lalu bersamaan dengan pembentukan tektonik pulau Sulawesi. Model bawah permukaan profil 1 seperti yang ditunjukkan pada Gambar 5.

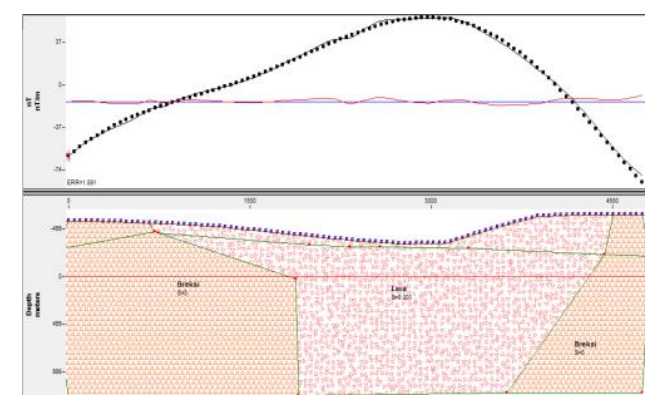

GAMBAR 5. Model Bawah Permukaan Dari Profil 1.

Profil 2 diambil sejauh 250 meter di bawah profil 1. Model yang ditampilkan pada Gambar 4.6 memiliki kesamaan dengan model pertama. Hal ini terjadi karena di bawah permukaan tersebut masih memiliki kesamaan batuan yang ada di bawahnya. Batuan breksi pada model kedua memiliki nilai suseptibilitas sebesar 0,00042 dan batuan lava sebesar 0,0012 dengan satuan cgs. panjang lintasan profil juga sekitar $5,5 \mathrm{~km}$ dengan kedalaman sekitar $1 \mathrm{~km}$, seperti yang ditunjukkan pada Gambar 6. 


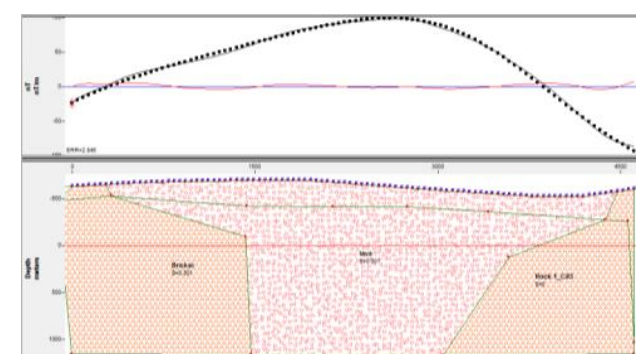

GAMBAR 6. Model Bawah Permukaan Dari Profil 2.

Profil 3 diambil dari arah utara menuju selatan dan memanjang 3,8 km dengan kedalaman $1 \mathrm{~km}$. Bentuk dan nilai suseptibilitas pada model ketiga memiliki nilai yang sedikit berbeda. Batuan breksi memiliki nilai suseptibilitas sebesar 0,00073 dan batuan lava memiliki nilai suseptibilitas 0,0012 dengan satuan cgs. Nilai breksi pada model ketiga karena profil 3 berbeda dengan profil 1 dan profil 2 karena profil 3 memanjang dari utara ke selatan berbeda dengan profil 1 dan profil 2 yang memanjang dari barat ke timur. Model ketiga dapat dilihat dari tampilan Gambar 7.

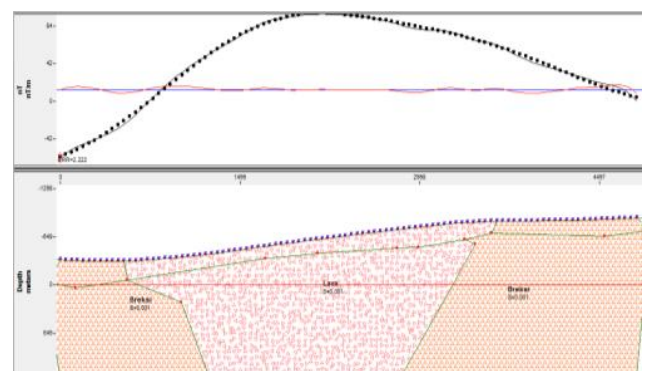

GAMBAR 7. Model Bawah Permukaan Dari Profil 3.

Profil 4 diambil $1 \mathrm{~km}$ sebelah timur dari profil 3. Model ini juga memanjang dari utara ke selatan dengan panjang lintasan sekitar $3.75 \mathrm{~km}$ dan kedalaman sekitar $1 \mathrm{~km}$. Pada model keempat memiliki bentuk dan nilai suseptibbilitas yang hampir sama dengan model ketiga. Ini terjadi karena profil 3 dan profil 4 memanjang dari utara hingga selatan dan membuat lintasan searah, dimana kemungkinan batuan yang tersusun di bawah permukaan profil 3 dan profil 4 memiliki kesamaan. Begitu pula dengan kesamaan yang terjadi pada profil 1 dan profil 2. Nilai suseptibilitas batuan breksi pada model keempat sebesar 0,00062 dan nilai suseptibilitas batuan lava adalah 0,001 dengan satuan cgs. model keempat dapat dilihat dari tampilan Gambar 8.

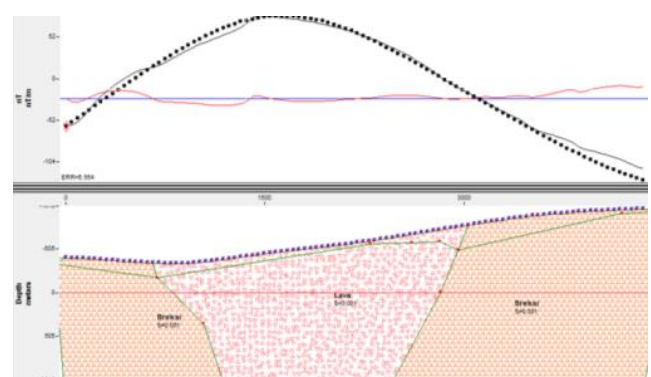

GAMBAR 8. Model Bawah Permukaan Dari Profil 4.

Dari keempat model bawah permukaan yang ditampilkan diketahui bahwa hulu Mamuju memiliki batuan breksi dan lava yang ada di bawah permukaan bumi. Model ini memberikan gambaran bahwa intrusi yang terjadi akibat lava yang keluar dari dalam bumi pada jutaan tahun yang lalu dan sebagian besar menjadikan pada daerah hulu mamuju terdapat kubah lava. 


\section{KESIMPULAN}

Berdasarkan pengolahan data magnetik di daerah Mamuju Sulawesi Barat dan hasil yang telah didapat pada penelitian ini, dapat disimpulkan bahwa:

1. Model yang dibuat merupakan gambaran bawah permukaan daerah penelitian. Anomali magnetik yang diperoleh dari penelitian yaitu terbesar yaitu $-760,1-231,8 \mathrm{nT}$, dimana daerah yang memiliki anomali tinggi yaitu di Hulu Mamuju yang merupakan bagian dari kompleks gunung api Adang.

2. Batuan bawah permukaan daerah yang diteliti memiliki struktur batuan breksi dan lava, dengan nilai suseptibilitas breksi $0,0006-0,0075$ satuan cgs dan lava $0,001-0,0015$ satuan cgs.

3. Penelitian ini merupakan penelitian awal dan dapat dilanjutkan dengan penelitianpenelitian berikutnya yang mampu menjelaskan daerah bawah permukaan secara detail.

\section{REFERENSI}

[1] Sukadana. I Gde dkk, Tataan Tektonik Batuan Gunung Api Di Komplek Adang Kabupaten Mamuju Provinsi Sulawesi Barat (Eksplorium, Jakarta, 2015), pp. 31-44.

[2] Santoso. Djoko, Pengantar Teknik Geofisika (Penerbit ITB, Bandung)

[3] Sopotan. Armstrong F, Struktur Geologi Sulawesi (Penerbit ITB, Bandung, 2012)

[4] Telford. et all, Aplied Geophysics 2nd edition (Cambridge University Press, New York, 1990)

[5] Reynold. Jhon M, An Introducction to Applied and Envirinmental Geophysics 2nd Edition (Jhon Willey \& sons Ltd, London, 2011)

[6] Andre, Koreksi Koreksi pada Pengolahan Data Geofisika, diakses pada tanggal 16 Nopember 2016.14.56jWIB (file:///I:IPersiapanIUGCIDraft\%20Proposal\%20Tugas\%20Akhir\%20Andre).

[7] Milsom. Jhon, Field Geophysics Edisi III (Jhon Willey \& Sons Ltd, London, 2003)

[8] Khoiri Zamroni dan Bagus Jaya Santosa, Studi Anomali Bawah Permukaan Daerah Sekitar Manifestasi Air Panas Desa Wagir Lor Kecamatan Ngebel Kabupaten Ponorogo Dengan Menggunakan Metode Magnetik, Jurnal Tugas Akhir ITS, Surabaya, 2013.

[9] Wahyudi. Dkk, Analisis Data Magnetik untuk Mengetahui Struktur Permukaan Daerah Manifestasi Airpanas di Lereng Utara Gunungapi Ungaran, Prosiding HAGI, Yogyakarta, 2004. 